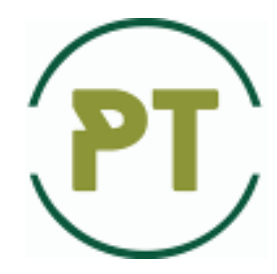

\title{
Evaluation of the suitability of introduction of multifunctional samples of aviation ground equipment in aircraft maintenance
}

\author{
O.N. Bilyakovych ${ }^{1 *}$, A.N. Savchuk ${ }^{2}$, Y.A. Turitsa ${ }^{2}$, L.V. Kurbet ${ }^{1}$ \\ ${ }^{I}$ National Aviation University, Kyiv, Ukraine \\ ${ }^{2}$ National Transport University, Kyiv, Ukraine \\ *E-mail:oleg65@voliacable.com
}

\begin{abstract}
Quite often there is an oversaturation of the platform with ground aircraft, which is designed for the operation of modern international airports, especially in the so-called "rush hour". The emergence of such a situation may affect the emergence of risks in the implementation of airport technologies, which are associated with a probable reduction in the level of safety of ground vehicles on the platform, the formation of clusters of aircraft maintenance at the parking lot and the possibility of damage to aircraft on the ground, psychological stress aviation personnel and other unforeseen situations.

To avoid melon situations that are directly related to the possible danger at airports, it is necessary to use multifunctional models of aviation ground equipment, which will provide several technological processes for ground handling of aircraft, passengers, mail and cargo by creating hybrid structures of special vehicles and equipment. and automation. For example, the use of multifunctional telescopic ladders allows not only to ensure a high level of comfort when boarding / disembarking passengers in aircraft, but also significantly increase the parking space in the buffer area of ground maintenance of aircraft for other types of ground aircraft by reducing the latter, which will increase the level of safety of aircraft maintenance and economic efficiency in the activities of airport services and handling companies.
\end{abstract}

Key words: aeronautical ground equipment, multifunctional ant samples, hybrid designs of special vehicles and means of mechanization and automation, multifunctional telescopic ladders.

\section{Presentation of the main material}

During the operation of modern international airports, especially during the so-called "rush hour", the platform is often oversaturated with aircraft ground equipment (AGE), designed for technical and commercial maintenance of aircraft (AIR). This situation can lead to additional risks in the implementation of airport technologies associated with the likely reduction in the level of safety of ground vehicles on the platform, the accumulation of aircraft maintenance at the parking lot, the possibility of damage to aircraft on the ground, psychological stress of aviation personnel, etc. [1].

One of the ways to overcome the above dangers at airports is the use of multifunctional AGE models that can provide several technological processes for ground handling of aircraft, air passengers, mail and cargo by creating hybrid designs of special vehicles and mechanization and automation.

The number of types and units of AGE involved in platform service is determined primarily by the volume of passenger and freight traffic in accordance with the seasonal schedule and daily flight plan of the aircraft, taking into account the requirements of airlines for the appropriate level of quality and efficiency of work, service air passengers, etc.

It is known that the number of types of AGE, which ensures the implementation of airport technology, is calculated by ten, not to mention the number of units for each type that can be simultaneously involved in platform work. The most common types of AGE include:

- refuelers; 
- aerodrome power supplies;

- aerodrome air conditioners;

- airfield tractors;

- passenger ladders;

- platform buses;

- container loaders;

- road trains from freight or container carts, etc.

The process of ground maintenance of the aircraft, illustrated in fig. 1, involving different types of AGE, can be optimized by reducing the units of ground equipment, which can be replaced by stationary equipment mounted, for example, on a telescopic ladder (passenger landing gallery).

It is well known that passenger landing galleries (PLG) are designed for boarding (disembarking) of passengers directly from the terminal building to the cabin of the aircraft without access to the platform, bypassing intermediate vehicles. Typically, such structures are installed at airports with a volume of passenger traffic exceeding 2 million passengers per year.

Currently, the evolution of the use of PLG is associated with the expansion of their functionality, which is confirmed in the developments of leading manufacturers of this type of AGE. In this regard, it is worth mentioning such companies as FMC (USA), CIMC (China), FMT (Sweden), which produce PLG with built-in aerodrome power sources (AC and DC power supply systems) and cabin air conditioning systems AIR [2].

In addition to combining the functions of a telescopic ladder (TL), an aerodrome air conditioner and an aerodrome power supply, it is also worth noting the possibility of solving another problem, in modern airports it is about transporting passengers with disabilities to the aircraft. It is the telescopic ladder that allows them to get on (with) the plane without delay, along with the general flow of passengers. The lack of stairs in the TL allows people with disabilities to move along the tunnels without undue effort, which speeds up the process of boarding and disembarking passengers and does not require additional involvement of such mechanization as ambulifts.

Therefore, when using multifunctional passenger galleries (air bridges) due to the technical means and technological capabilities they provide, there may be a reduced need for some types of special vehicles.

The time of service cycle of aircraft by special vehicle depends on the type and model of the aircraft, the required volumes and types of work that is performed when using this type of aviation ground equipment.

When using PLG with built-in air-conditioning and power supply system of the aircraft during the calculation of the number of mechanization means it is possible to remove them from the final result.

In order to plot the dependence of the amount of ground equipment on the result of the implementation of multifunctional ladders, the information on the intensity of air traffic at the Boryspil International airport and technical capabilities of terminal complexes was analyzed. The graph shows the number of GPUs and selfpropelled ladders that have been in use by handling companies over the last 15 years and with the prospect of expanding the airport's terminal D to 2025.



Fig. 1. Scheme of ground maintenance of the B737 aircraft 
Based on the data obtained during the calculation and taking into account the statistical indicators of the airport, you can make a schedule of the actual and projected number of certain types of aviation special equipment at the airport, taking into account the introduction of multifunctional passenger galleries (fig. 2).

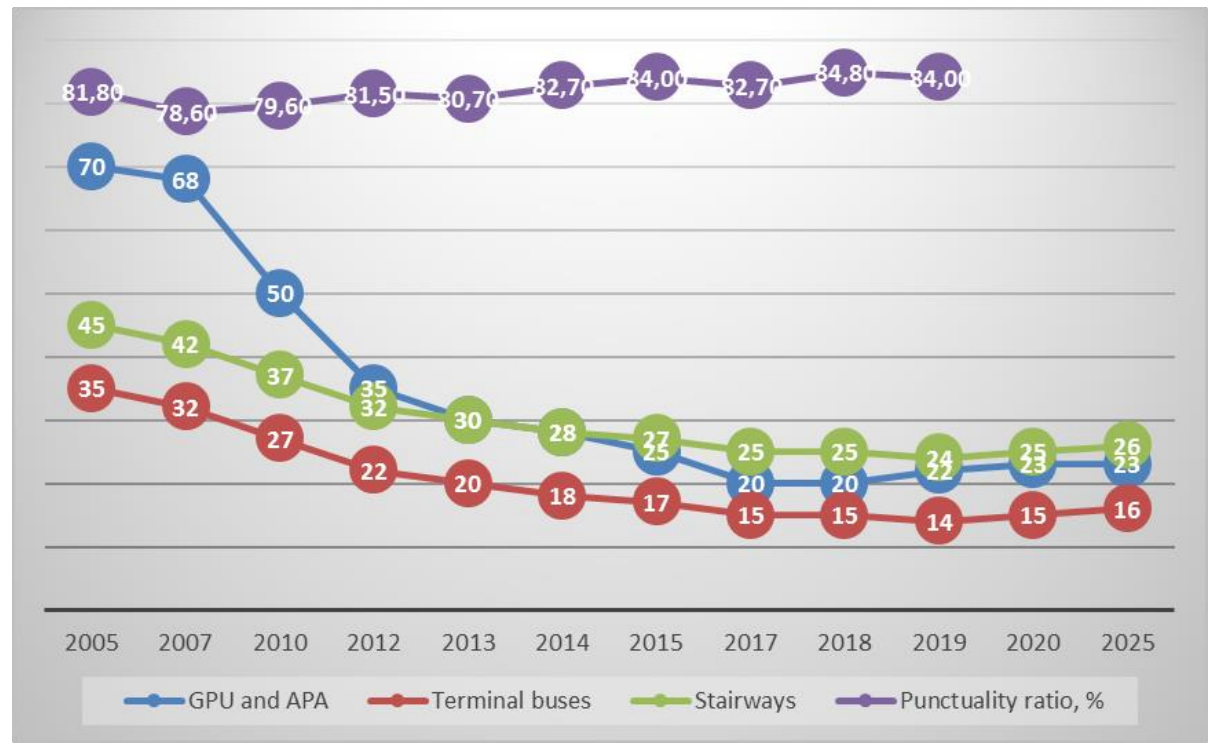

Fig.2. The actual and projected number of certain types of aviation special equipment at the airport, taking into account the introduction of multifunctional PLG

The turnaround time (TAT) of an aircraft is defined as the time that passes from when an aircraft lands until it takes off again for a new flight. During this period, the resources of the airline involved and the airport are mobilized to get the aircraft set up in the shortest possible time [3].

One of the most time-consuming processes for servicing an airplane is boarding and disembarking passengers.

When using passenger ramps, the required time on delivering passengers on the apron is reduced due to the lack of this need. The average time to complete one leg by the average terminal bus is 5-7 minutes, the average capacity of one bus is 100 passengers. As well as the capacity of one B 737 aircraft is 189 passengers, a minimum of 2 buses are required for handle 1 flight.

TAT has hence become a very important and key parameter in determining the profitability of an airline company. Such situations can lead to a lot of undesirable consequences, as it has a direct impact on the survival of the organization due to a series of payment crisis one after another.

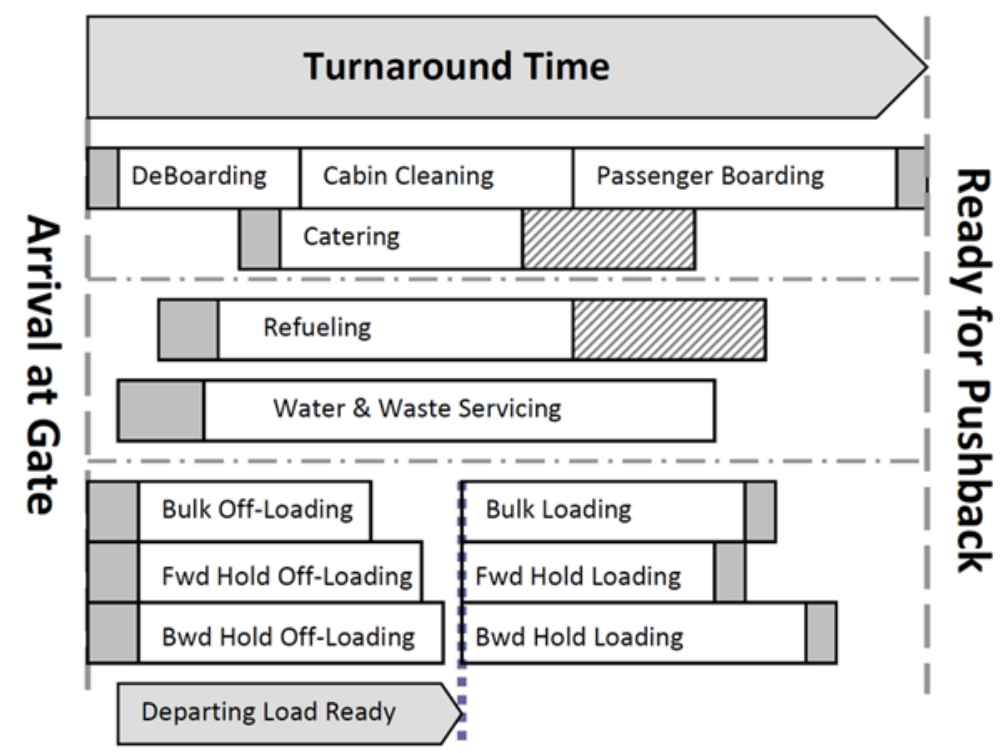

Fig.3. Turnaround time distribution [4] 
It is also necessary to consider the design of the airport, cause with the hub model of the airport most passengers use such airports like transit point of their journey and the time for a transfer from one flight to another, for example from international to domestic, is very important.

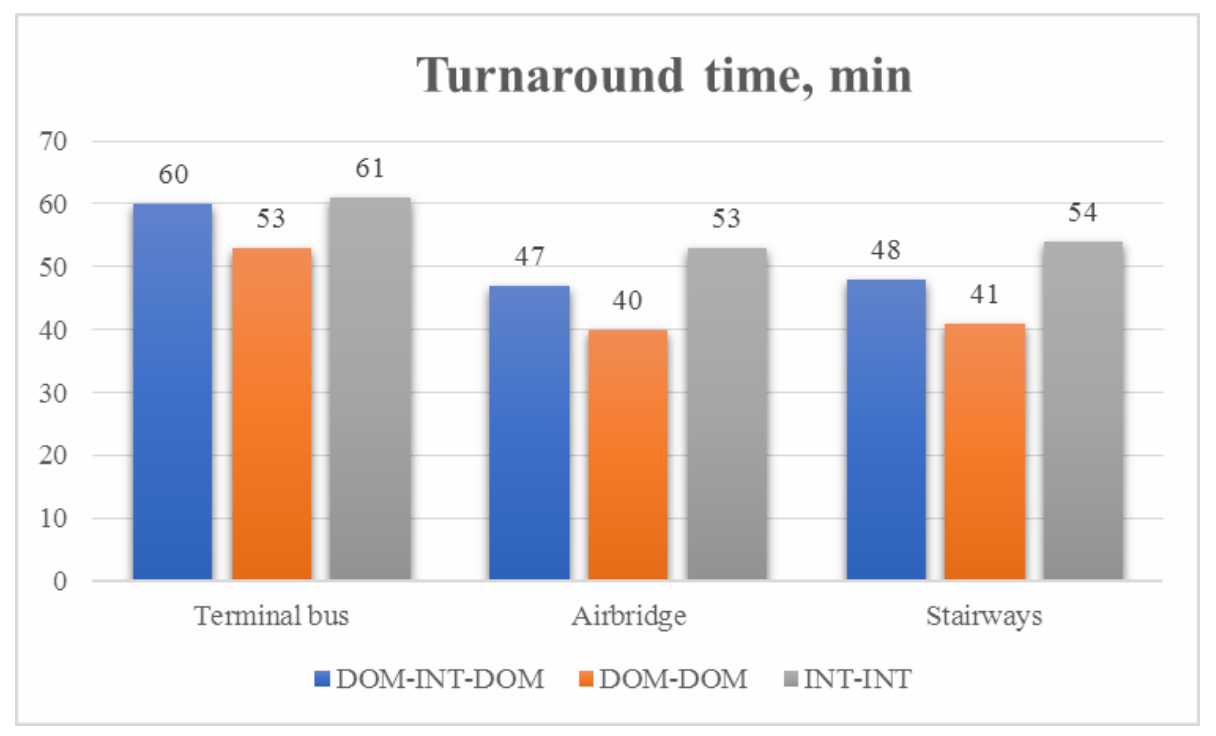

Fig. 4. Turnaround time for different means

\section{Conclusions}

Thus, the use of multifunctional passenger landing galleries allows not only to provide a high level of comfort when boarding / disembarking passengers in the aircraft, but also significantly increase the parking space in the buffer area of ground handling of aircraft for other types of AGE by reducing the latter, which will increase safety. and economic efficiency in the activities of airport services and handling companies. The above design solutions are, of course, promising provided that the requirements of the feasibility of combining several types of AGE and ensuring a high level of reliability of such developments.

\section{Refrences}

1. Білякович О.М. Аеродромно-технічне забезпечення польотів: конспект лекцій / О.М.Білякович. - К.: НАУ-друк, 2009. -84 с.

2. Білякович О.М. До питання багатофункціональності авіаційної наземної техніки / О.М.Білякович // Матеріали IX міжнародного науково-практичного семінару «Авіаційна наземна техніка: наукові дослідженні, виробництво, експлуатація та підготовка персоналу», травень 2018 р.: тези доп. К.: Асоціація «Аеропорти України» цивільної авіації, 2018. - С.10.

3. Passenger Boarding Bridge [Електронний pecypc]. - Режим доступу: https://www.skybrary.aero/index.php/Passenger_Boarding_Bridge

4. Airport passenger boarding bridges [Електронний pecypc]. - Режим доступу: https://www.adelte.com/airports/passenger-boarding-bridg 
Білякович О.М., Савчук А.М., Туриця Ю.О., Курбет Л.В. Оцінка доцільності впровадження багатофункціональних зразків авіаційної наземної техніки при обслуговуванні повітряних суден

Досить часто спостерігається перенасиченість перону засобами авіаційної наземної техніки (АНТ), яка призначена при експлуатації сучасних міжнародних аеропортів, особливо, у так звані, «години пік».Поява такої ситуації може вплинути на появу ризиків в процесі реалізації аеропортових технологій, які пов'язані з ймовірним зменшенням рівня безпеки руху наземних транспортних засобів по перону, утворенням скупчення засобів обслуговування ПС на місці їх стоянки та імовірною можливістю пошкодження літаків на землі, психологічним напруженням авіаційного персоналу та іншими непередбачуваними ситуаціями.

Для уникнення диних ситуацій, які безпосередньо повязані з можливою небезпекою в аеропортах $\epsilon$ необхідність використання багатофункціональних зразків АНТ, що дасть можливість забезпечити проведення декількох технологічних процесів з наземного обслуговування ПС, авіапасажирів, обробки пошти та вантажів шляхом створення гібридних конструкцій спецмашин та засобів механізації $\mathrm{i}$ автоматизації. Так, наприклад застосування багатофункціональних телескопічних трапів дозволяє не тільки забезпечити високий рівень комфорту при посадці/висадці пасажирів в ПС, а й суттєво збільшити паркувальний простір в буферній зоні наземного обслуговування літаків для інших типів АНТ за рахунок скорочення одиниць останніх, що сприятиме підвищенню рівня безпеки обслуговування ПС та економічної ефективності у діяльності аеропортових служб та хендлінгових компаній.

Ключові слова: авіаційна наземна техніка (ант), багатофункціональні зразки ант, гібридні конструкції спецмашин та засобів механізації і автоматизації, багатофункціональні телескопічні трапи 